\title{
IMPLEMENTASI JSON PARSING PADA APLIKASI MOBILE E-COMMERCE Studi Kasus : CV V3 Tekno Indonesia

\author{
${ }^{1,2,3}$ Program Studi Teknik Informatika, Fakultas Sains dan Teknologi \\ Universitas Islam Negeri Syarif Hidayatullah Jakarta

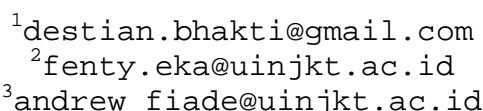 \\ Bhakti Destian Wijaya ${ }^{1}$, Fenty E.M.A ${ }^{2}$, dan Andrew Fiade ${ }^{3}$
}

Abstrak: Sistem operasi Android saat ini merupakan salah satu dari sekian banyak sistem operasi pada smartphone yang sedang mengalami pertumbuhan pesat di dunia, khususnya di Indonesia. CV Vitiga Tekno Indonesia bergerak di bidang pemasaran gadget membutuhkan media marketing yang dapat diakses secara online selain website yaitu melalui smartphone. Oleh karena itu penelitian ini berfokus pada bagaimana membuat aplikasi mobile e-commerce pada smartphone Android, dengan cara mengambil data yang berasal dari website, dan kemudian ditampilkan ke dalam sebuah aplikasi, menggunakan metode HTTP Connection dan JSON Parsing. Pembuatan aplikasi menggunakan bahasa pemrograman Java, dengan bantuan tools IDE Eclipse dan MySQL untuk database server. JSON berkomunikasi melalui Application Program Interface (API) bertujuan untuk menghubungkan aplikasi mobile dengan database yang ada di dalam server. Pada penelitian ini API ialah kumpulan source code PHP, yang isinya adalah query untuk mengambil data dari website, yang hasilnya di-encode ke dalam bentuk JSON.

Kata Kunci: Mobile e-commerce, JSON Parsing, Application Program Interface (API).

Abstract: Nowadays, Android operating sistem is one of the existing operating systems on smartphones that growing rapidly. CV Vitiga Tekno Indonesia is a company in the marketing gadget requires marketing media that can be accessed online via smartphone. Therefore, this research focuses on how to make a mobile $e$ commerce application on the Android smartphone, by taking data that comes from a website, and then show into a user as an application, using the HTTP Connection method through JSON Parsing. The mobile e-commerce application is built using java programming language / IDE Eclipse and MySQL tools for the database server. JSON, communicates through Application Program Interface (API), aims to connect mobile applications with the existing database on the server. In this study, API is a collection of queries that retrieve data from the website in $\mathrm{PHP}$ language. The results are encoded into JSON form.

Keywords: Mobile e-commerce, JSON parsing, Application Program Interface (API).

\section{PENDAHULUAN}

Saat ini, CV V3 Tekno Indonesia adalah sebuah perusahaan yang menjual berbagai macam gadget dan menggunakan website sebagai media marketing untuk menjangkau para konsumennya. Dengan bertumbuh pesatnya sistem operasi Android, CV V3 Tekno Indonesia ingin mempunyai sistem dan media marketing yang baru selain website.

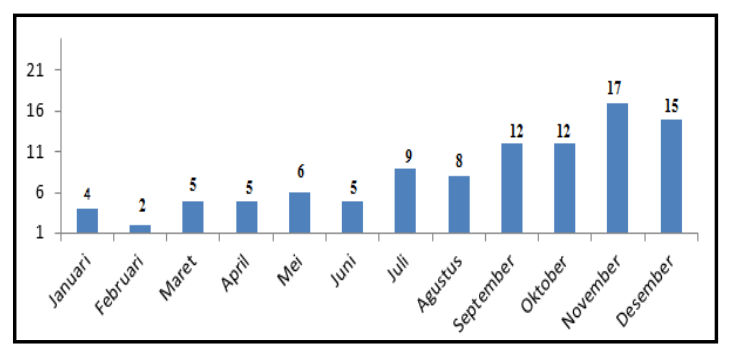

Gambar 1. Peningkatan transaksi perdagangan gadget selama tahun 2013 melalui www.vitigaon.com

Berdasarkan Gambar 1, diketahui bahwa selama tahun 2013 ada peningkatan transaksi perdagangan gadget melalui website. Hal ini menunjukkan adanya minat konsumen yang cukup besar untuk bertransaksi secara online. Oleh karena itu, perlu dilakukan terobosan baru untuk memberi kemudahan konsumen bertransaksi melalui 
smartphone yaitu dengan membuat aplikasi berbasis Android tentang vitigaon.com. Aplikasi ini dibuat dengan mengacu pada database website vitigaon.com sehingga data yang ditampilkan akan sama dengan yang ada di website.

Aplikasi e-commerce yang diakses atau diinstal pada smartphone disebut juga mobile e-commerce. Aplikasi ini memakai teknologi JSON Parsing yang ada di dalam android melalui HTTP Connection. Sehingga aplikasi website yang ada saat ini dapat terintegrasi dengan aplikasi yang ada di handset. Hal ini menyebabkan jika terjadi perubahan data di dalam sisi aplikasi website, perubahan data tersebut terjadi pada aplikasi handset. Dibandingkan dengan hanya sekedar menggunakan webview, tentunya JSON Parsing akan lebih unggul dari segi resource yang dikeluarkan ketika memuat content yang berasal dari aplikasi website.

Webview adalah sebuah component yang ada di dalam sistem operasi Android yang berfungsi untuk memuat sebuah tampilan website ke dalam bentuk tampilan mobile web. Webview menampilkan secara serupa dengan tampilan sesungguhnya di desktop. Webview memuat sendiri semua atribut yang ada di website seperti button, text, image dan lain sebagainya dengan format HTML. Tentunya aktifitas ini memerlukan konsumsi data yang lebih banyak. Berbeda dengan JSON Parsing dalam HTTP Connection, tampilan yang baru dari sisi aplikasi mobile dapat dibuat dengan cara memilih sendiri data atau informasi apa saja yang ingin ditampilkan pada aplikasi. Dengan demikian pada saat aplikasi berjalan, aplikasi hanya akan memuat jenis content yang sudah ditentukan dan tidak akan memuat content dari website secara keseluruhan persis seperti website aslinya.
Berdasarkan latar belakang tersebut diatas, maka tujuan penelitian ini adalah membuat sebuah aplikasi mobile e-commerce pada smartphone Android, dengan menerapkan JSON parsing untuk menampilkan data dari website. Pada aplikasi yang dibuat, terdapat sistem transaksi Business-ToBusiness (B2B) dan Business-To-Consumer (B2C). Sistem B2B terjadi antara CV V3 Tekno Indonesia dengan mitra bisnisnya (para Reseller) dan B2C adalah antara CV V3 Tekno Indonesia dengan pengguna akhir barang dagangan.

Sebelum melaksanakan penelitian dilakukan jajak pendapat kepada 50 orang pengguna smartphone yang diantaranya adalah konsumen CV V3 Tekno Indonesia, mengenai perlu dibuatnya aplikasi mobile e-commerce untuk memudahkan transaksi. Hasilnya adalah 64\% responden menjawab perlu adanya aplikasi yang menunjang transaksi perdagangan di smartphone. Dengan demikian hasil penelitian ini diharapkan dapat membuktikan manfaat JSON Parsing pada pembuatan aplikasi mobile e-commerce baik bagi pemilik bisnis maupun kosumennya.

\section{LANDASAN TEORI}

2.1. Sekilas Tentang JSON (Java Script Object Notation)

JSON (Java Script Object Notation) adalah format pertukaran data yang bersifat ringan, disusun oleh Douglas Crockford. Fokus JSON adalah pada representasi data di website [1][2][4][5]. JSON dirancang untuk memudahkan pertukaran data pada situs dan merupakan perluasan dari fungsi-fungsi javascript.

Contoh teks php dalam memformat hasil query berupa format JSON:

$<$ ?php

include_once("conn.php");

\$sql = "SELECT * FROM penjualan"; 
\$query $=$ mysql_query $(\$ s q l) ;$

$\$$ data $=\operatorname{array}()$;

while(\$row=mysql_fetch_object(\$query))

$\{\$$ data []$=\$$ row; $\}$

\$response

array('status'=> "Ok",'item'=> \$data);

echo json_encode(\$response)

?>

Luaran JSON dari kode diatas adalah sebagai berikut :

\{"status":"Ok","item":[\{"id":"1","bulan":"Janu ari","total":"700"\},\{"id":"2","bulan":"Februari","t otal":"400"\},\{"id":"3","bulan":"Maret","total":"20 0"\},\{"id":"4","bulan":"April","total":"800"\},\{"id": "5","bulan":"Mei","total":"700"\},\{"id":"6","bulan ":"Juni","total":"230"\},\{"id":"7","bulan":"Juli",,t otal":"400"\},\{"id":"8","bulan":"Agustus","total":" 350"\},\{"id":"9","bulan":"September","total":"800" \},\{"id":"10","bulan": "Oktober","total":"350"\},\{"id ":"11","bulan":"November","total":"400"\},\{"id":" 12","bulan":"Desember","total":"600"\}]\}

\subsection{JSON parsing}

Penggunaan JSON Parsing dalam HTTP Connection ini bertujuan untuk memberi kemudahan bagi user ketika menggunakan aplikasi ini. Dengan adanya JSON Parsing dalam HTTP Connection, informasi yang ada didalam website dapat ditampilkan di dalam sebuah aplikasi mobile[3]. Hal ini menyebabkan aplikasi mobile tidak perlu menampilkan seluruh content yang ada didalam website seperti halnya pada mobile web browser. Aplikasi android akan memilih jenis konten yang ingin ditampilkan, seperti halnya gambar, item description, dan lain-lain.

Dalam JSON Parsing, kita membutuhkan API (Application Program Interface) yang berfungsi untuk menghubungkan antara aplikasi mobile dan aplikasi website[3].
Pada penelitian ini API ialah kumpulan source code berbasis PHP, yang isinya adalah Query untuk mengambil data dari website, yang hasilnya di-encode ke dalam bentuk JSON. Pada saat aplikasi mobile mengirimkan request untuk menampilkan data (SELECT * FROM) dari website, API akan meneruskannya sesuai dengan Query yang tepat untuk menampilkan data (SELECT * FROM). Setelah data diambil, kemudian di- ENCODE ke dalam bentuk JSON, dan diteruskan ke dalam aplikasi mobile. Di dalam aplikasi mobile, JSON tersebut di-parsing ke dalam bentuk yang kita inginkan, misalnya dalam bentuk list. Gambar 2 menunjukkan arsitektur JSON parsing.

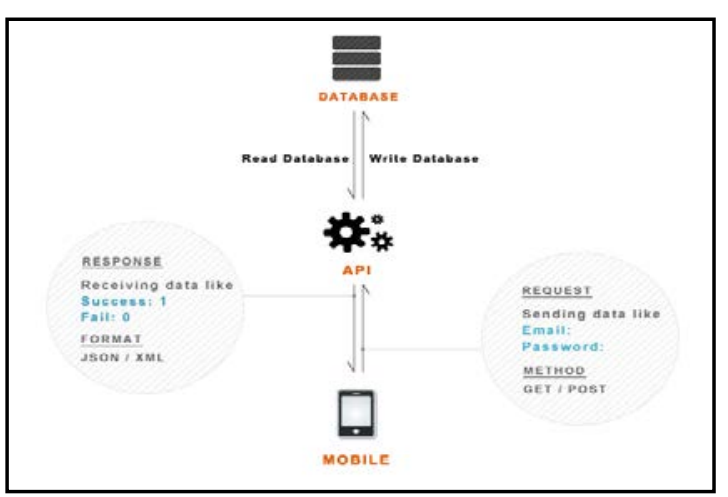

Gambar 2. Arsitektur JSON parsing

\section{ANALISIS SISTEM BERJALAN}

Pada Gambar 3 menunjukkan sistem yang saat ini berjalan di CV V3 Tekno Indonesia. Saat ini, perusahaan menggunakan website sebagai media ecommmerce untuk menjangkau pelanggannya. Calon pembeli dapat mengakses website perusahaan untuk melakukan transaksi maupun hanya sekedar melihat item. Di dalam website tidak tersedia fitur review item yang lebih lengkap sehingga calon pembeli dapat melihat review item melalui mesin pencari Google. Setelah melakukan pemesanan, pembeli melakukan konfirmasi pembayaran dengan cara menelpon langsung ke Customer Service dari CV V3 Tekno Indonesia, 
ataupun melalui e-mail yang berisikan bukti pembayaran yang di upload. Setelah itu CV V3

Tekno Indonesia meresponnya dengan cara mencocokannya dengan data di database.

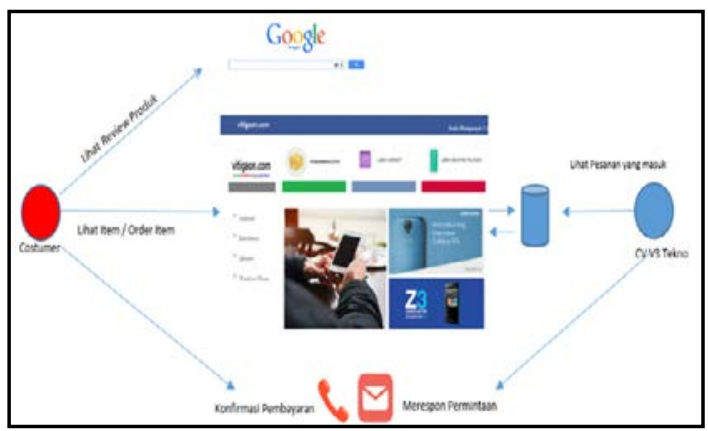

Gambar 3. Rich Picture Sistem Berjalan

Berdasarkan rich picture sistem yang berjalan pada saat ini, penulis melakukan sebuah analisa terkait permasalahan yang ada.

1. Dengan tampilan website yang statis seperti pada saat ini, para calon pembeli akan kesulitan ketika mengakses websitenya lewat mobile phone, khususnya Android. Sehingga penulis berkesimpulan, perlu dibangun sebuah aplikasi berbasis Android untuk menjangkau calon pembeli yang mengaksesnya lewat mobile phone.

2. Dengan website yang ada pada saat ini, hanya terdapat fitur pemesanan saja. Sehingga kegiatan lain yang termasuk di dalam $e$ commerce, seperti halnya konfirmasi pembayaran, dan permintaan status transaksi, tidak dapat dilakukan di dalam satu aplikasi (aplikasi). Sehingga penulis berkesimpulan perlu di buat sejumlah fitur seperti konfirmasi pembayaran, permintaan status, dan review item yang akan ada di dalam satu aplikasi (mobile).

\section{EKSPERIMEN}

\subsection{Gambaran Sistem Yang Diusulkan}

Berdasarkan analisis yang dilakukan, penulis mengusulkan sebuah sistem yang baru dengan penjelasan sebagai berikut (Gambar 4):
1. Semua kegiatan yang ada di dalam e-commerce (order, konfirmasi pembayaran, permintaan status) dapat dilakukan di dalam satu aplikasi (mobile).

2. Data yang ditampilkan di dalam aplikasi berasal dari database website vitigaon.com. sehingga data yang ada di dalam website sama dengan data yang ditampilkan di aplikasi mobile.

3. Data exchange menggunakan format JSON dengan metode Parsing dalam HTTP Connection

4. Pembayaran dilakukan dengan cara transfer.

5. Konfirmasi pembayaran dilakukan dengan cara mengisi form didalam aplikasi

6. Permintaan status transaksi dilakukan di dalam aplikasi dengan mengirimkan nomor invoicenya.

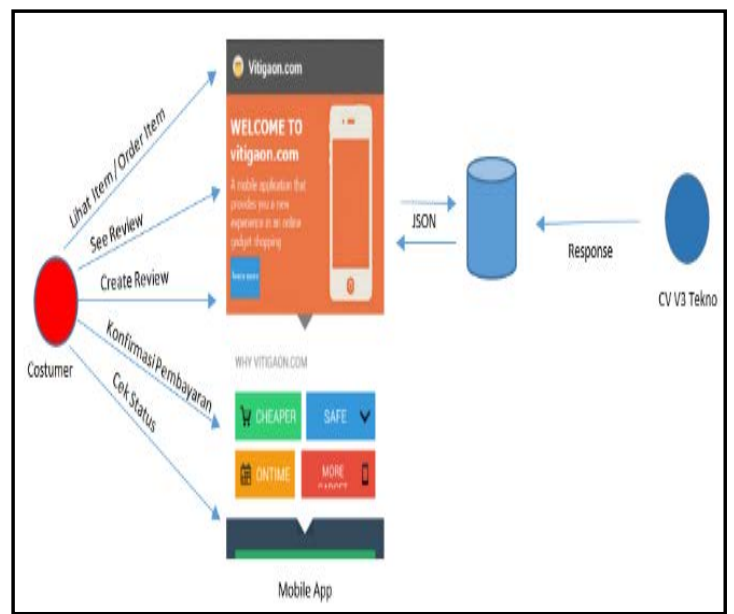

Gambar 4. Rich Picture Sistem Usulan

\subsection{Metode Pembayaran}

Pada saat pembeli telah selesai melakukan transaksi, pembeli akan mendapatkan email konfirmasi dari vitigaon.com berupa detail pesanan dan jumlah harga beserta nomor Invoice-nya. Kemudian pembayaran dilakukan dengan cara transfer bank sesuai yang tertera di invoice. Pada saat transfer, pembeli diharuskan mengirim sejumlah uang sesuai dengan total transaksi yang 
dilakukan ditambah dengan nomor invoice 3 digit dibelakangnya. Contoh penulisan jumlah yang harus ditransfer oleh pembeli dapat dilihat pada Tabel 1.

Tabel 1. Contoh Jumlah Pembayaran

\begin{tabular}{|l|l|l|}
\hline Jumlah transaksi & $\begin{array}{l}\text { Invoice } \\
\text { number }\end{array}$ & $\begin{array}{l}\text { Jumlah yang } \\
\text { harus di transfer }\end{array}$ \\
\hline Rp. 4.000.000 & 111 & Rp. 4.000.111 \\
\hline
\end{tabular}

Hal ini bertujuan untuk memudahkan vitigaon.com dalam melacak pembeli yang sudah melakukan transfer. Selanjutnya vitigaon.com akan mengecek apakah sesuai dengan form konfirmasi yang telah di isi oleh pembeli jika sudah melakukan pembayaran.

\subsection{Perancangan entitas}

Pada tahap ini dirancang dan ditentukan entitasentitas yang terdapat di dalam sistem. Entitasentitas tersebut adalah :

1. Seller (vitigaon.com)

2. User untuk Reseller

3. User untuk grosir

4. Kategori item

5. Object item

6. Cart

7. Tutorial

8. Review

\subsection{Perancangan Arsitektur Aplikasi}

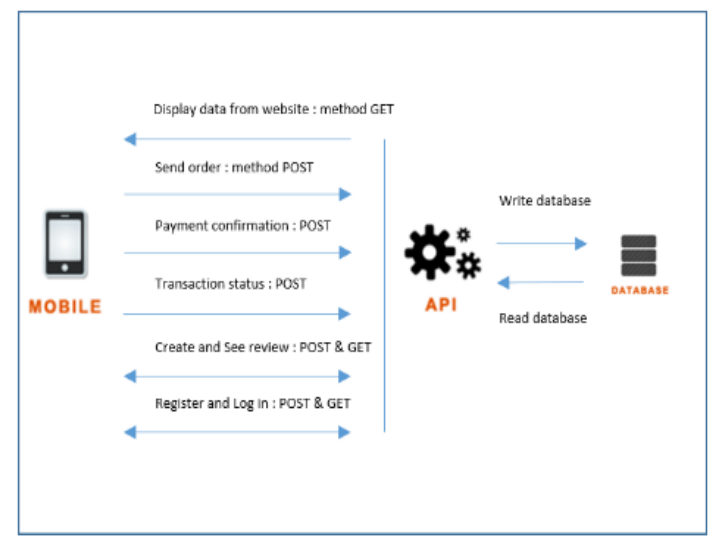

Gambar 5. Arsitektur aplikasi
Berdasarkan Gambar 5 mengenai arsitektur aplikasi, secara umum gambaran sistem sebagai berikut :

- Aplikasi menampilkan data dari website dengan metode GET

- Aplikasi mengirim data pesanan (order), konfirmasi pembayaran dan status order dengan metode POST

- Aktivitas create dan see review menggunakan metode POST dan GET secara bergantian.

- Proses pendaftaran (register) dan masuk ke aplikasi (login) menggunakan metode POST dan GET.

\subsection{Perancangan sistem}

4.5.1 Menentukan Aktor dan Membuat Use Case

Tabel 2. Identifikasi Aktor

\begin{tabular}{|l|l|l|}
\hline No & Aktor & \multicolumn{2}{|c|}{ Deskripsi } \\
\hline 1 & Buyer & $\begin{array}{l}\text { Pengguna aplikasi yang } \\
\text { berperan sebagai pembeli } \\
\text { yang membeli product } \\
\text { dalam satuan eceran. } \\
\text { (B2C) }\end{array}$ \\
\hline 2 & Reseller & $\begin{array}{l}\text { Pengguna aplikasi yang } \\
\text { berperan sebagai pembeli } \\
\text { yang membeli product } \\
\text { dalam satuan grosir. (B2B) }\end{array}$ \\
& &
\end{tabular}

aplikasi, review dari gadget yang ada didalam aplikasi, dan juga dapat login ke dalam aplikasi atau daftar sebagai user jika belum terdaftar. Reseller juga dapat melihat previlege bila menjadi user dengan level Reseller (Gambar 6).

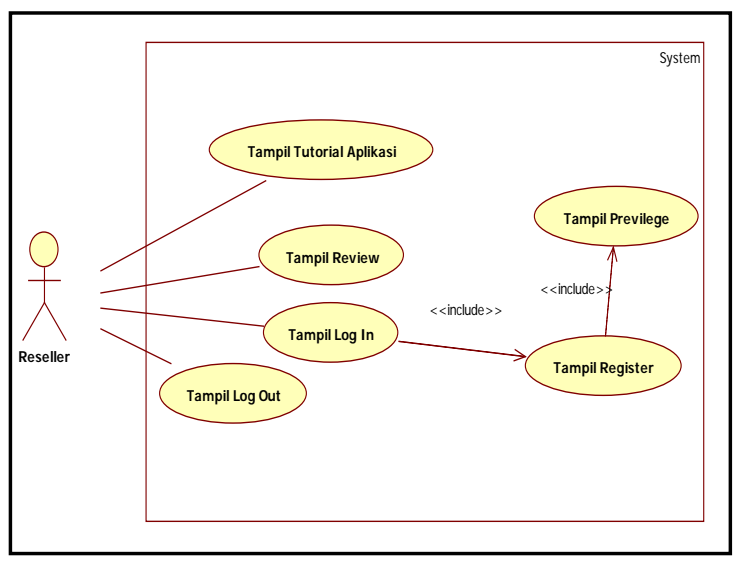

Gambar 6. Usecase Diagram Reseller Bagian 1 


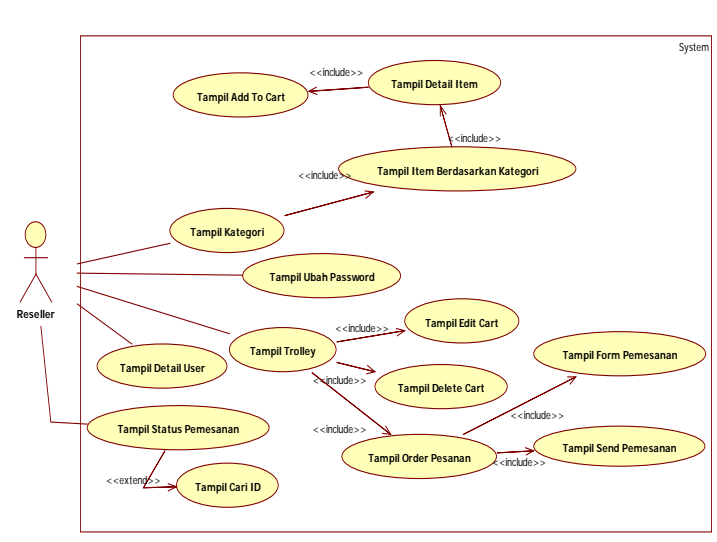

Gambar 7. Usecase Diagram untuk Reseller bagian 2

Setelah login, proses yang terjadi sebagai berikut (Gambar 7):

- Reseller dapat melihat bermacam-macam kategori untuk memulai transaksi. Setelah sesuai dengan keinginan, reseller dapat menambahkan item yang dipilihnya ke dalam sebuah cart. Ketika sudah selesai dalam memilih item untuk dibeli, reseller dapat melanjutkan ke proses berikutnya yaitu tampil trolley.

- Di dalam proses trolley ini, reseller dapat mengedit dan menghapus cart nya jika ingin membatalkan transaksi. Setelah selesai, reseller dapat memesan barang dengan cara mengisi form pemesanan yang disediakan oleh aplikasi.

- Kemudian data dari form pemesanan tersebut akan masuk ke dalam database aplikasi. Selain itu reseller juga dapat mengedit user profilnya seperti mengganti password yang baru untuk proses log in. Reseller juga dapat melihat status pengiriman atau pemesanan dengan cara memasukan ID transaksi.

\subsubsection{Perancangan database}

Database yang digunakan adalah database yang ada pada server aplikasi website vitigaon.com, yang telah ditambahkan sesuai dengan kebutuhan untuk fitur tambahan pada aplikasi mobile. Dengan demikian, data dan

informasi yang ditampilkan di dalam aplikasi yang dibuat, sama dengan yang ditampilkan di aplikasi website. Sehingga transaksi yang sedang berlangsung di aplikasi web maupun mobile dapat berjalan langsung secara real time dan tersimpan di dalam satu database.

Berikut adalah rincian database yang penulis gunakan :

Nama database

Lokasi database

Jumlah tabel

\subsubsection{Pembuatan API (Application Program Interface)}

Application Program Interface (API) bertujuan untuk menghubungkan aplikasi mobile dengan database yang ada di dalam server. API ini nantinya untuk memenuhi seluruh jenis fungsi yang dibutuhkan di dalam aplikasi. Seperti fungsi tampil item, fungsi edit item, fungsi POST transaksi, dan lain sebagainya[5]. API ini pada akhirnya akan di-hosting secara online sehingga dapat diakses secara online (Gambar 8).

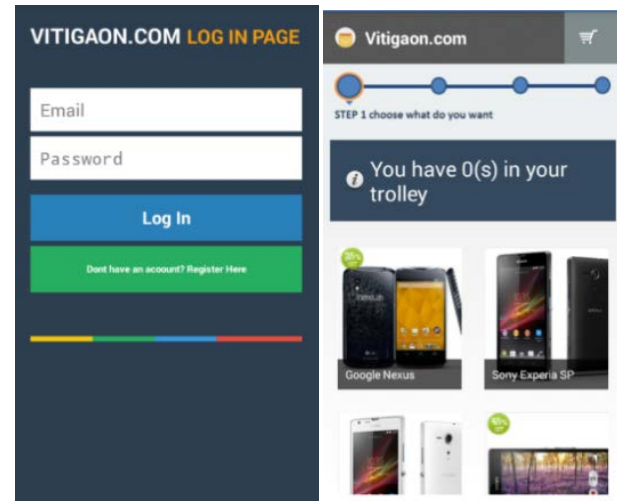

Gambar 8. Rancangan Interface

\subsubsection{Implementasi JSON Parsing}

1. Aplikasi mobile ingin menampilkan data produk dari database website. Yang pertama kali di lakukan, adalah membuat API. API berisi Query SELECT*FROM. Seperti di bawah ini : 


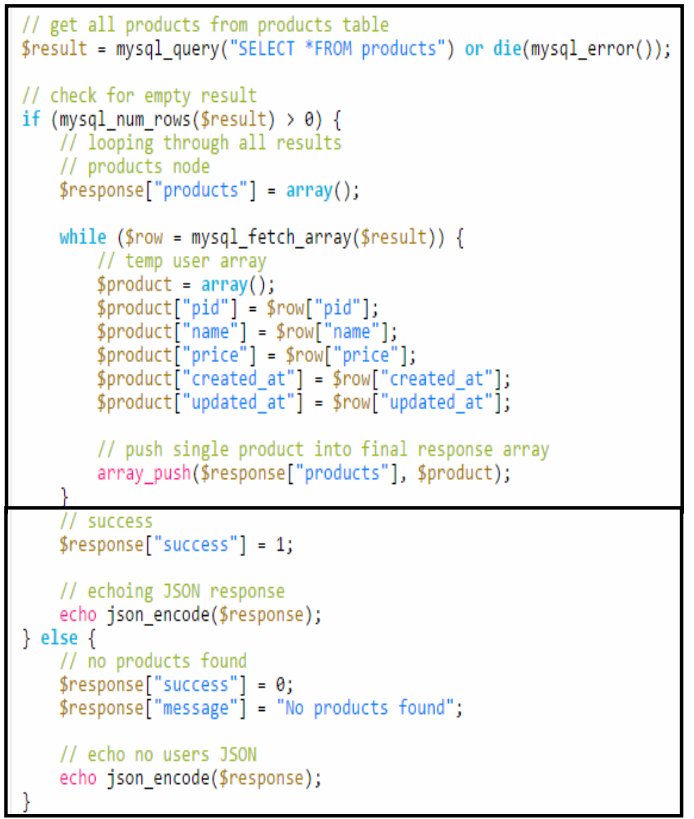

Source code tersebut berbasis PHP, berisikan Query SELECT, dan jika data ditemukan, data di "echo" ke dalam bentuk JSON ("echo json_encode").

Jika source code tersebut dijalankan, maka akan tampil JSON code seperti di bawah ini :

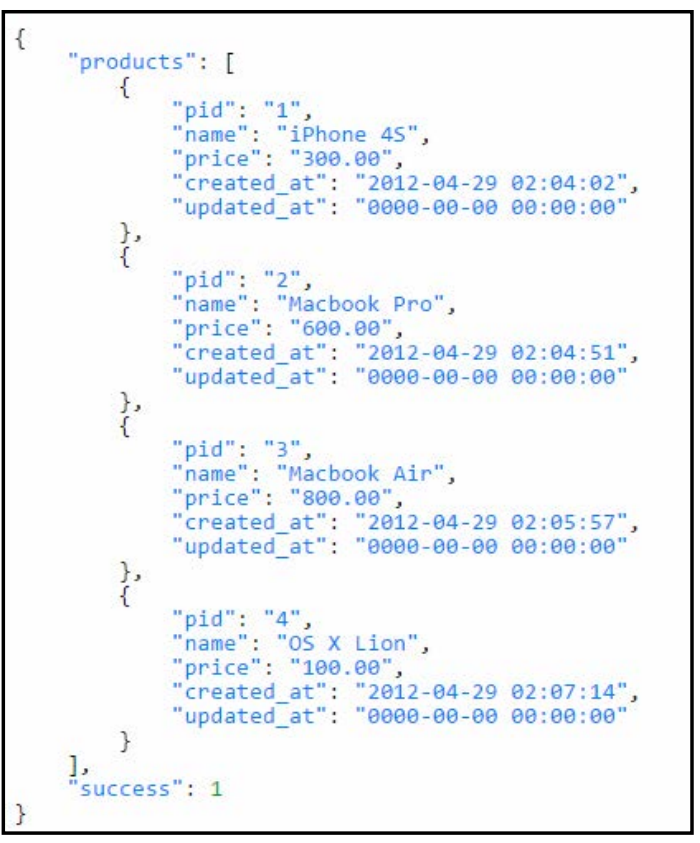

Ini adalah bentuk JSON dari data hasil Query dari API yang di buat. Selanjutnya, JSON code ini akan dilanjutkan ke dalam aplikasi mobile untuk di-parse. Caranya sebagai berikut: dari sisi aplikasi android, yang pertama di lakukan adalah menentukan tampilan antarmuka untuk menampilkan JSON yang akan di-parsing nantinya.
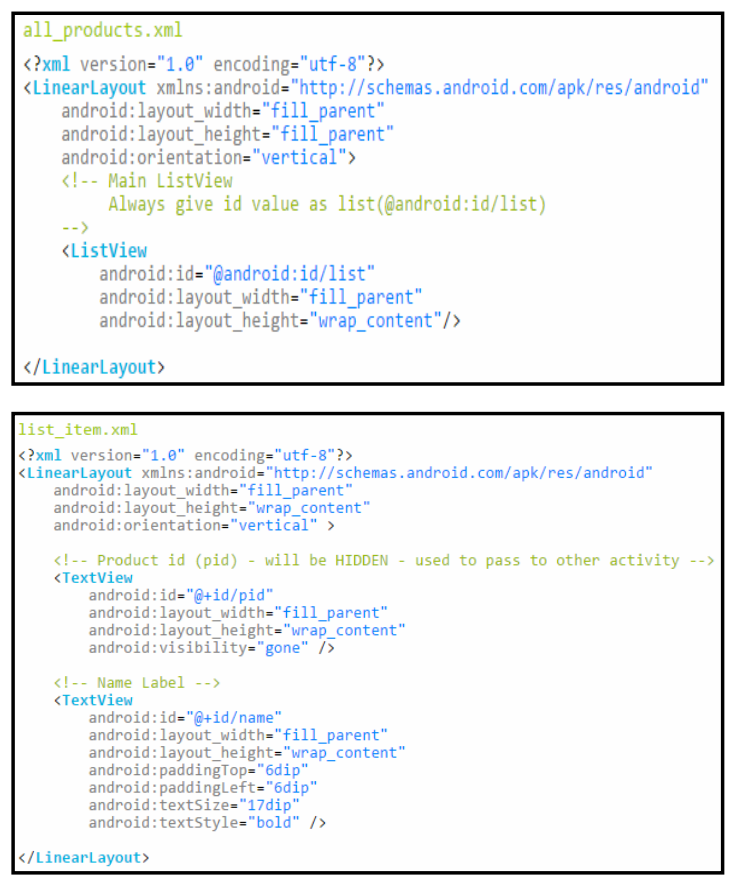

Kemudian ketika dibangun lagi sebuah Class yang akan digunakan untuk proses parsing

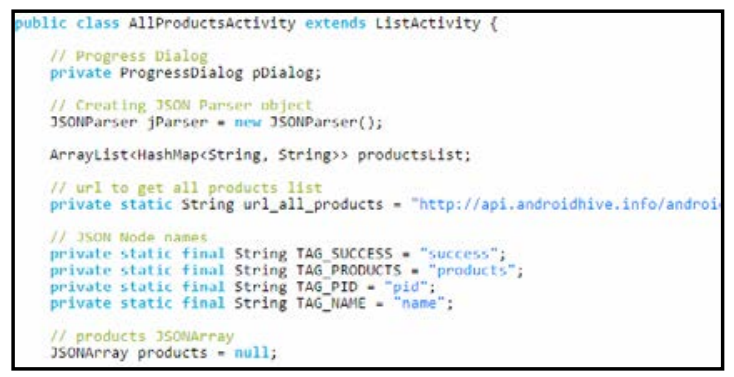

maka terbentuk class dengan METHOD JSON parser, dan dengan proses inisialisasi dari API dalam bentuk URL.

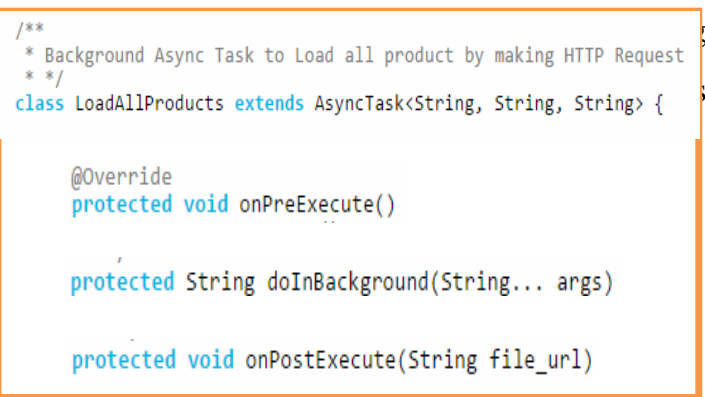


Class tersebut berisikan 3 method :

- onPreExecute : adalah metode yang akan di proses sebelum proses koneksi dilakukan.

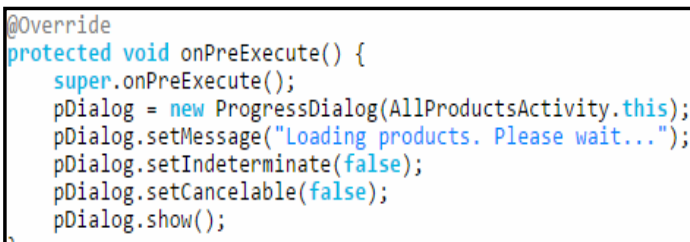

- doInBackGround : adalah metode yang akan di proses di dalam background aplikasi. Disinilah proses PARSING terjadi.

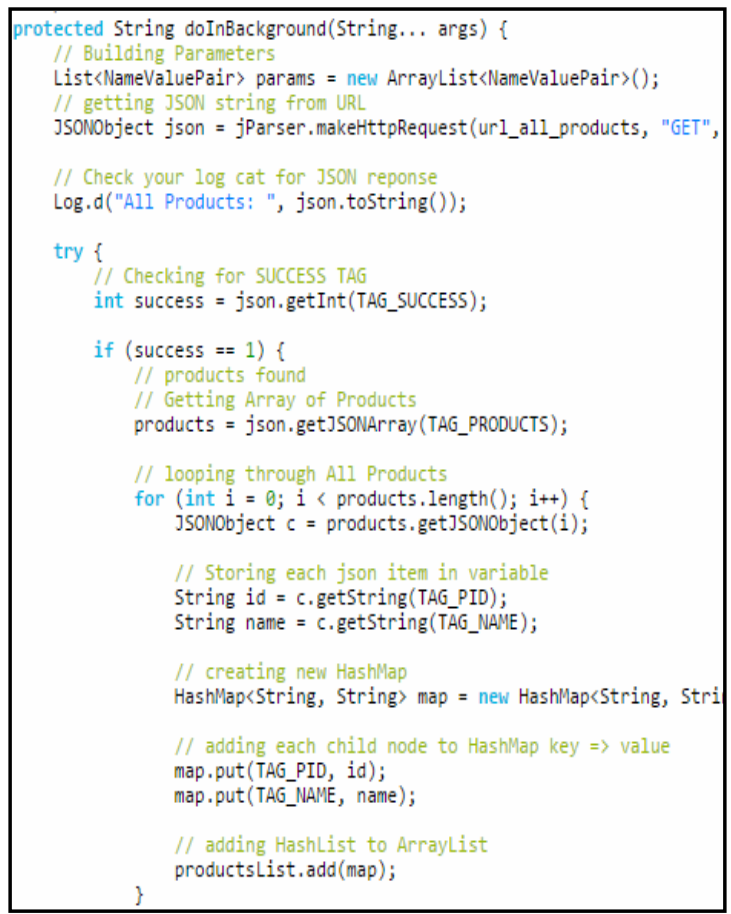

- onPostExecute : adalah metode yang akan di proses setelah Parsing dilakukan.

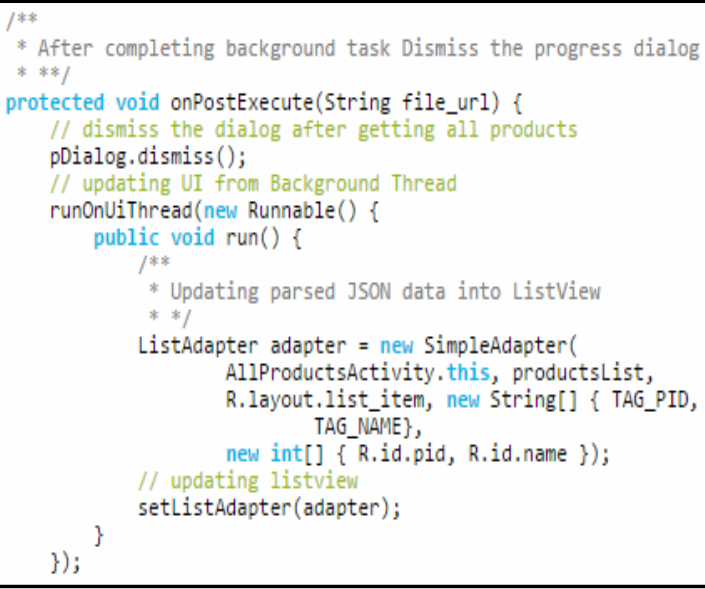

Gambar 9 adalah hasil akhir tampilan mobile application.

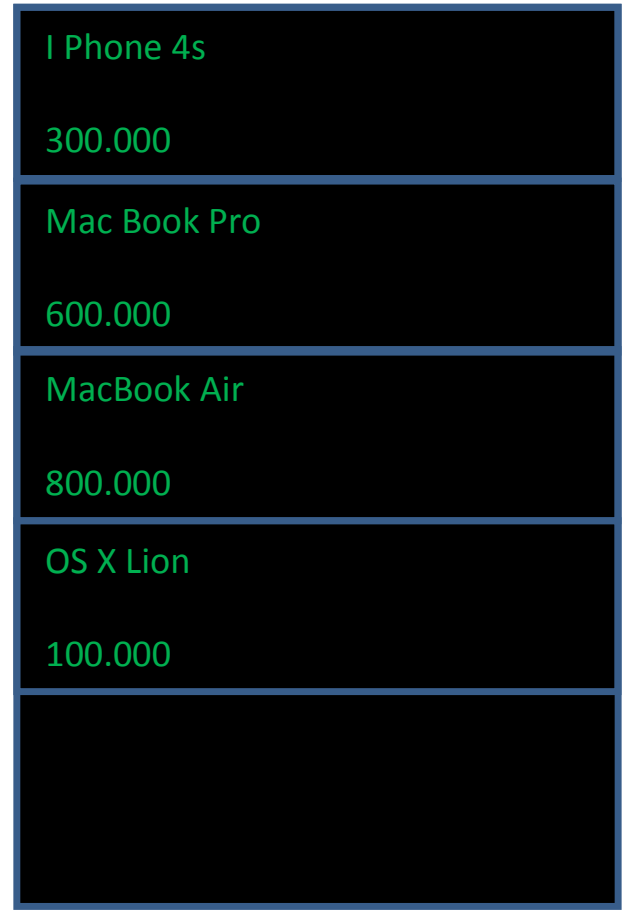

Gambar 9. Tampilan Mobile Application

4.6 Implementasi

4.6.1 Instalasi API ke Internet

Tahap ini, API (Application Program Interface) yang dibuat diinstal ke dalam hosting internet. Proses ini dilakukan dengan tujuan API dapat berjalan secara online. API di-hosting ke dalam server website dari vitigaon.com. Sehingga untuk mengakses nya dapat melalui URL : vitigaon.com/API . 
4.6.2 Instalasi Aplikasi ke dalam Handset

Proses ini dilakukan untuk mengetahui apakah aplikasi yang dibuat dapat berjalan di perangkat sesungguhnya. Berikut adalah proses instalasi aplikasi ke dalam handset.
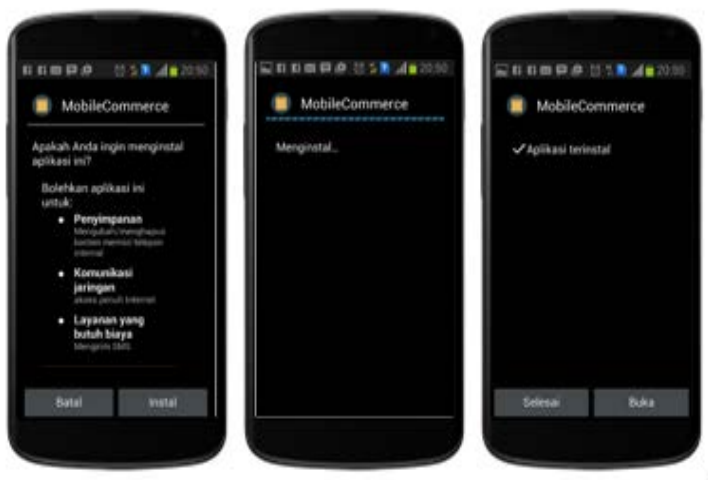

Gambar 10. Instalasi di Handset

\subsubsection{Pengujian Blacbox}

Pengujian Black Box dilakukan untuk mengetahui apakah fungsi dan alur aplikasi dapat berjalan sesuai dengan harapan.

1. Fungsi register account dapat berjalan sesuai dengan harapan.

2. Proses $\log$ in untuk masing-masing user dapat berjalan sesuai dengan harapan.

3. Proses menampilkan halaman Reseller dan halaman buyer masing-masing dapat berjalan sesuai dengan harapan.

4. Proses transaksi buyer dan transaksi Reseller dapat berjalan sesuai dengan harapan, di antaranya :

a) Proses tampil kategori dapat berjalan sesuai dengan harapan

b) Proses memilih item dapat berjalan sesuai dengan harapan.

c) Proses edit trolley dapat berjalan sesuai dengan harapan.

d) Proses mengirim pesanan dapat berjalan sesuai dengan harapan

e) Proses menerima email konfirmasi dapat berjalan sesuai dengan harapan. f) Proses konfirmasi pembayaran dapat berjalan sesuai dengan harapan

g) Proses meminta status transaksi dapat berjalan sesuai dengan harapan.

\section{KESIMPULAN DAN SARAN}

5.1 Kesimpulan

Berdasarkan hasil penelitian diperoleh kesimpulan:

1. Aplikasi mobile e-commerce yang dikembangkan oleh CV V3 Tekno menggunakan data yang berasal dari satu database yang sama, yaitu yang digunakan oleh website.

2. Manipulasi data yang berasal dari database vitigaon.com dilakukan dengan data exchange dalam format JSON, yang kemudian di-parse ke dalam aplikasi Android.

\subsection{Saran}

1. Dalam aplikasi ini, diharapkan adanya fitur dimana user / buyer dapat melihat sendiri status transaksinya sehingga tidak memerlukan fitur kirim SMS untuk melakukannya.

2. Diharapkan dalam aplikasi ini terdapat fitur upload gambar ketika ingin melakukan konfirmasi pembayaran.

\section{REFERENSI}

[1] Chasseur, Craig., Li, Y., dan Patel, Jm. Enabling JSON Document Stores in Relational Systems. Sixteenth International Workshop on the Web and Databases (WebDB 2013). 2013.

[2] Google. Package Summary. HTTP://developer.android. com/reference/android/app/package-summary.html di akses pada 10 September 2014. 2014.

[3] Peng, Dunlu., Cao, Lidong., dan Xu, Wenjie. Using JSON for Data Exchanging in Web Service Application. Journal of Computational Information Sistem, volume 16, page 5883-5890. 2011.

[4] Safaat, Nazruddin. Android (Pemograman Aplikasi Mobile Smartphone dan Tablet PC Berbasis Android). Informatika, Bandung. 2011.

[5] W3Schools, JSON Tutorial, 2013, HTTP://www.w3schools.com/json/. 2013.. 